\title{
Numerical Model of Geochronological Tracers for Deposition and Reworking Applied to the Mississippi Subaqueous Delta
}

\author{
JJ Birchler \\ Virginia Institute of Marine Science \\ Courtney K. Harris \\ Virginia Institute of Marine Science \\ TA Kniskern \\ Virginia Institute of Marine Science \\ CR Sherwood
}

Follow this and additional works at: https://scholarworks.wm.edu/vimsarticles

Part of the Aquaculture and Fisheries Commons

\section{Recommended Citation}

Birchler, JJ; Harris, Courtney K.; Kniskern, TA; and Sherwood, CR, Numerical Model of Geochronological Tracers for Deposition and Reworking Applied to the Mississippi Subaqueous Delta (2018). Journal Of Coastal Research.

10.2112/SI85-092.1

This Article is brought to you for free and open access by the Virginia Institute of Marine Science at W\&M ScholarWorks. It has been accepted for inclusion in VIMS Articles by an authorized administrator of W\&M ScholarWorks. For more information, please contact scholarworks@wm.edu. 


\section{Numerical Model of Geochronological Tracers for Deposition and Reworking Applied to the Mississippi Subaqueous Delta}

Author(s): Justin J. Birchler, Courtney K. Harris, Tara A. Kniskern, and Christopher R. Sherwood

Source: Journal of Coastal Research, 85(sp1):456-460.

Published By: Coastal Education and Research Foundation

https://doi.org/10.2112/SI85-092.1

URL: http://www.bioone.org/doi/full/10.2112/SI85-092.1

BioOne (www.bioone.org) is a nonprofit, online aggregation of core research in the biological, ecological, and environmental sciences. BioOne provides a sustainable online platform for over 170 journals and books published by nonprofit societies, associations, museums, institutions, and presses.

Your use of this PDF, the BioOne Web site, and all posted and associated content indicates your acceptance of BioOne's Terms of Use, available at www.bioone.org/page/terms_of_use.

Usage of BioOne content is strictly limited to personal, educational, and non-commercial use. Commercial inquiries or rights and permissions requests should be directed to the individual publisher as copyright holder. 


\title{
Numerical Model of Geochronological Tracers for Deposition and Reworking Applied to the Mississippi Subaqueous Delta
}

\author{
Justin J. Birchler ${ }^{\dagger}{ }^{*}$, Courtney K. Harris ${ }^{\dagger}$, Tara A. Kniskern ${ }^{\dagger}$, and Christopher R. Sherwood \\ $\dagger$ Virginia Institute of Marine Science \\ College of William \& Mary \\ Gloucester Point, VA USA \\ $\S$ Now at: U.S. Geological Survey $¥$ U.S. Geological Survey \\ Saint Petersburg, FL USA Woods Hole, MA USA \\ *jbirchler@usgs.gov
}

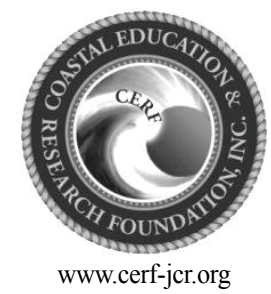

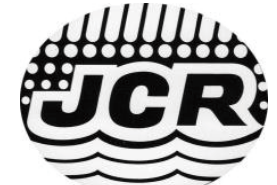

www.JCRonline.org

\section{ABSTRACT}

Birchler, J.J.; Harris, C.K.; Kniskern, T.A., and Sherwood, C.R., 2018. Numerical model of geochronological tracers for deposition and reworking applied to the Mississippi subaqueous delta. In: Shim, J.-S.; Chun, I., and Lim, H.S. (eds.), Proceedings from the International Coastal Symposium (ICS) 2018 (Busan, Republic of Korea). Journal of Coastal Research, Special Issue No. 85, pp. 456-460. Coconut Creek (Florida), ISSN 0749-0208.

Measurements of naturally occurring, short-lived radioisotopes from sediment cores on the Mississippi subaqueous delta have been used to infer event bed characteristics such as depositional thicknesses and accumulation rates. Specifically, the presence of Beryllium-7 ( ${ }^{7} \mathrm{Be}$ ) indicates recent riverine-derived terrestrial sediment deposition; while Thorium-234 $\left({ }^{234} \mathrm{Th}\right)$ provides evidence of recent suspension in marine waters. Sediment transport models typically represent coastal flood and storm deposition via estimated grain size patterns and deposit thicknesses, however, and do not directly calculate radioisotope activities and profiles, which leads to a disconnect between the numerical model and field observations. Here, observed radioisotopic profiles from the Mississippi subaqueous delta cores were directly related to a numerical model that represented resuspension and deposition using a new approach to account for the behavior of short-lived radioisotopes. Appropriate selection of parameters such as the biodiffusion coefficient, sediment accumulation rate, and radioisotopic source terms enabled a good match between the modeled and observed cores. Comparisons of modelled profiles with geochronological analytical models that estimate accumulation rate and flood layer thickness revealed potential avenues for refining these tools, and highlight the importance of constraining the biodiffusion coefficient.

ADDITIONAL INDEX WORDS: Sediment transport model, Mississippi subaqueous delta, radioisotopes.

\section{INTRODUCTION}

Naturally occurring, short-lived radioisotopic tracers have been used to characterize sediment deposition in many coastal environments. For example, ${ }^{7} \mathrm{Be}$ has been used to infer recent deposition of fluvially-derived sediment (Kniskern et al., 2014; Sommerfield, Nittrouer, and Alexander, 1999), while the presence of ${ }^{234} \mathrm{Th}$ indicates recent resuspension in marine waters (McKee, DeMaster, and Nittrouer, 1984). Assessments of flood sediment budgets and deposition rates derived from radioisotopic data are often based on conceptual or analytical models that rely on estimated rates of mixing and burial (e.g. Nittrouer et al., 1984; Palinkas et al., 2005). Meanwhile, coastal sediment transport models typically restrict their calculations to erosion and deposition, grain size distributions, and changes to sediment deposit thickness (i.e. Warner et al., 2008). Validation of such models has often relied on comparison to observed radioisotopic profiles, however. For example, Xu et al. (2016) compared model estimates of deposit thicknesses from Hurricanes Katrina and Rita with an evaluation based on observed geochronological data in the northern Gulf of Mexico from Goñi et al. (2007).

Corbett, McKee, and Duncan (2004) related differences in the sediment bed radioisotopic profiles and inferred depositional rates from two sampling periods to seasonal variations in the northern Gulf of Mexico. At their 'near river' site (red triangle in Figure 1), they obtained radioisotope activity profiles of ${ }^{7} \mathrm{Be}$ and ${ }^{234} \mathrm{Th}$ with depth in the sediment bed in April and October, 2000.

DOI: $10.2112 /$ SI85-092.1 received 30 November 2017; accepted in revision 10 February 2018

*Corresponding author: jbirchler@usgs.gov

${ }^{\circ}$ Coastal Education and Research Foundation, Inc. 2018
The seafloor here predominantly consists of mud and is influenced by wave reworking, and freshwater and sediment discharge from the Mississippi River. Bioturbation did not appear to be intense, based on analysis of X-radiographs and lack of macro-fauna obtained during core collection (Corbett, McKee, and Duncan, 2004). From April to October, 2000, the site experienced high river discharge that then decreased, low wave energy, and significant deposition (Figure 2). The high inventories of ${ }^{7} \mathrm{Be}$ in October, 2000 were attributed to spring and summer sediment deposition, while the elevated ${ }^{234} \mathrm{Th}$ inventories were explained by increased wave energy at the end of the period (Corbett, McKee, and Duncan, 2004)

While standard sediment transport models (i.e. Warner et al., 2008) can not directly test these interpretations, a newly

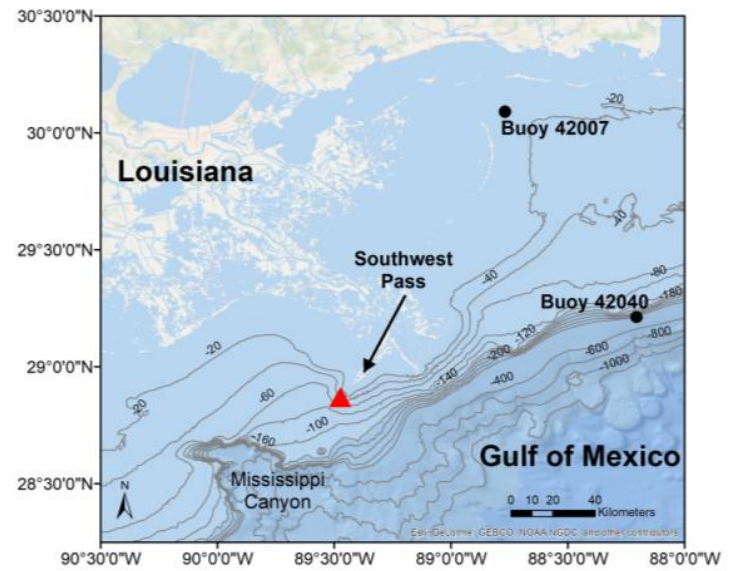

Figure 1: Mississippi River Delta, Gulf of Mexico, USA. Model location indicated by triangle. Buoys used shown as circles. 
developed model accounts for both radioisotope activities and sediment transport (Birchler et al., submitted). This paper discusses application of the coupled model to the radioisotopic cores for the Mississippi subaqueous delta measured by Corbett, McKee, and Duncan (2004) and use of the model to evaluate the applicability of analytically based estimates of deposition rates.
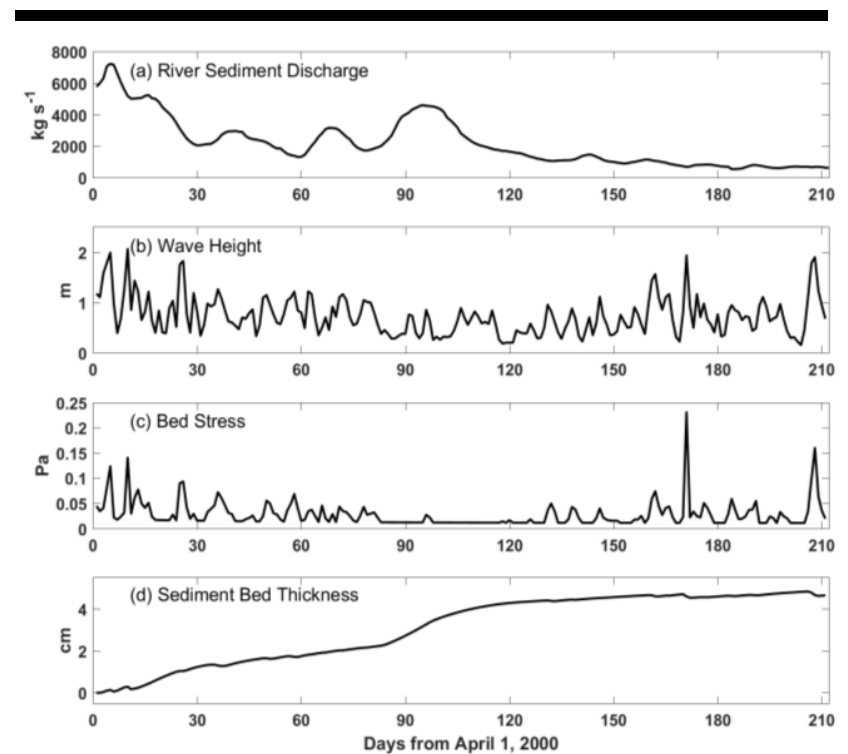

Figure 2: Time-series used to represent April, 2000 to October, 2000; (a) measured river sediment discharge (USGS, https://waterdata.usgs.gov), (b) wave heights measured by NDBC buoys, (c) bed stress calculated by model, and (d) modeled bed thickness.

\section{METHODS}

A one-dimensional (vertical) version of the Community Sediment Transport Modeling System (CSTMS; Warner et al., 2008), within ROMS (Regional Ocean Modeling System; see Haidvogel et al., 2008; Shchepetkin and McWilliams, 2005) was used. Recently, Moriarty et al. (2017) introduced both particulate and dissolved geochemically reactive tracers in the seabed and the water column. Using a similar framework, Birchler et al. (submitted) developed a model to directly estimate activities of radioisotopes ${ }^{7} \mathrm{Be}$ and ${ }^{234} \mathrm{Th}$. The one-dimensional model was implemented to represent the 'near river' site offshore of the Mississippi delta sampled by Corbett, McKee, and Duncan (2004) (Figure 1). This section summarizes the model configuration. Birchler, Harris, and Kniskern (2018) provides an archive of the model code, input, and output.

The model used 30 uniformly spaced layers in the vertical to represent the $50 \mathrm{~m}$ water column, while the sediment bed model had 40 layers that were each initially $0.5 \mathrm{~cm}$ thick. Two grain sizes were used to represent mud, with diameters of 0.015 and $0.063 \mathrm{~mm}$; settling velocities of 0.01 and $0.1 \mathrm{~cm} \mathrm{~s}^{-1}$; and critical shear stresses of 0.03 and $0.08 \mathrm{~Pa}$, respectively. The erosion rate parameter (see Warner et al., 2008) was chosen as $5 \times 10^{-5} \mathrm{~kg} \mathrm{~m}^{-2}$ $\mathrm{s}^{-1}$ so that the model produced erodibility curves consistent with those measured near the Mississippi delta by Xu et al. (2014). As the model proceeded, newly delivered river sediment supplied ${ }^{7} \mathrm{Be}$. For suspended material, ${ }^{234} \mathrm{Th}$ was reset to maintain a constant activity, which supplied ${ }^{234} \mathrm{Th}$ to the bed during cycles of sediment resuspension and deposition. A constant wind speed of $15 \mathrm{~m} \mathrm{~s}^{-1}$ was applied to create steady currents of about $10 \mathrm{~cm}$ $\mathrm{s}^{-1}$. For input timeseries, hourly wave height and period were taken from buoys 42040 and 42007 (Figure 1) from the National Oceanic and Atmospheric Administration National Data Buoy Center (NDBC, 2013).

One-dimensional (vertical) models of sediment transport typically neglect horizontal flux convergences and divergences that lead to net erosion or deposition. The study location accumulates $\sim 1-3 \mathrm{~cm}$ of new sediment per month, however, and at times also supplies sediment that is eroded and redistributed to downstream locations (Corbett, McKee, and Duncan, 2004). Source and sink terms were therefore added as surface tracer fluxes $\left(\mathrm{m} \mathrm{s}^{-1}\right)$ to represent Mississippi River sediment delivered to, or eroded sediment removed from, the study site from April to October, 2000. The timing of the surface tracer source was input at a rate proportional to the observed river sediment discharge at Tarbert Landing, MS, obtained from the U.S. Geological Survey (Figure 2a). The surface tracer flux was scaled so that a total of $4.6 \mathrm{~cm}$ of sediment was deposited to produce modeled radioisotope profiles that matched those reported in Corbett, McKee, and Duncan (2004). Episodic erosion coincided with the four wave resuspension events where the bed shear stress exceeded $0.1 \mathrm{~Pa}$ (Figure 2c). To account for removal and erosion of sediment, roughly $50 \%$ of suspended material was removed as a surface tracer flux during timesteps when the bed shear stress exceeded $0.1 \mathrm{~Pa}$. The sediment deposition, erosion, and input radioisotope activity were chosen to replicate observed penetration depths and activity profiles. The main choices made to match the profiles were the biodiffusion coefficients and deposition rates used, and the activity of new sediment (Birchler, 2014).

The model represented April to October, 2000 (Figure 2). Because the data from October, 2000 had ${ }^{234} \mathrm{Th}$ observations only for the very surface sample (Corbett, McKee, and Duncan, 2004), the effort to reproduce the observed profiles focused mainly on ${ }^{7} \mathrm{Be}$ (Figure 3). A low, but non-zero, biodiffusion rate was needed in the model to obtain reasonable penetration depths. Biodiffusion was implemented as described in Sherwood et al. (in press), where $D_{b, \max }$ was $0.95 \mathrm{~cm}^{2} \mathrm{yr}^{-1}\left(3 \times 10^{-12} \mathrm{~m}^{2} \mathrm{~s}^{-1}\right), D_{b, \min }$ was 0.016 $\mathrm{cm}^{2} \mathrm{yr}^{-1}\left(5 \times 10^{-14} \mathrm{~m}^{2} \mathrm{~s}^{-1}\right)$ and $Z_{b, \max }$ was $3 \mathrm{~cm}$.

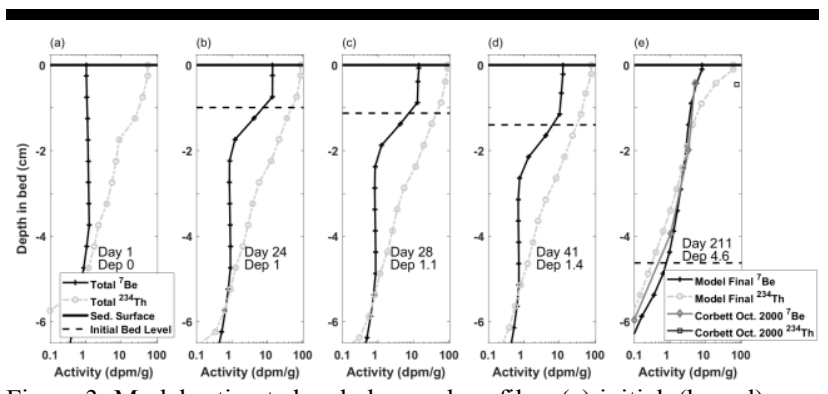

Figure 3: Model estimated and observed profiles; (a) initial, (b, c, d) intermediate profiles, and (e) final measured and modeled profiles after seven months. Text in each panel denotes day of model run and amount of net sediment deposition to that day in $\mathrm{cm}$. 
When biodiffusion was neglected, the surface activity of both radioisotopes was slightly too high, and the penetration depth was too shallow (Birchler, 2014).

The radioisotope activity profiles were initialized with those found in April, 2000 by Corbett, McKee, and Duncan (2004) (Figure 3a). For ${ }^{7} \mathrm{Be}$, a source activity of $20 \mathrm{dpm} \mathrm{g}^{-1}$ was needed to match the final observed ${ }^{7} \mathrm{Be}$ surface activity from October, 2000. A value of $95 \mathrm{dpm} \mathrm{g}^{-1}$ was chosen for the water column activity of ${ }^{234} \mathrm{Th}$ in order to match the high surface activity observed in October, 2000. Because nearly all of the modeled deposition occurred in the first half of the time period, ${ }^{7} \mathrm{Be}$ needed a reasonably high input activity as its signal decayed significantly by the simulation's end.

To investigate the role of biodiffusion on radioisotope profiles, two additional models were run that were identical except for the maximum bioturbation rates; the models had bioturbation rates of 0 and $25 \mathrm{~cm}^{2} \mathrm{yr}^{-1}$, respectively.

\section{RESULTS}

The profiles of ${ }^{7} \mathrm{Be}$ and ${ }^{234} \mathrm{Th}$ changed through time from the initial profile due to sediment deposition, decay, and reworking due to waves and bioturbation (Figure 3a-e). Time series of surface activities, inventories, and penetration depths calculated for both radionuclides illustrates their response to sediment erosion and deposition (Figure 2, 4). Peaks in ${ }^{7} \mathrm{Be}$ and ${ }^{234} \mathrm{Th}$ surface activity were associated with fluvial delivery, but did not scale directly with discharge, which was largest early in the model (days 0-15) when seabed activities continued to reflect initial conditions (Figure 2). Instead, peak surface activities co-occurred with a smaller river pulse around day 100 , when bed stresses were smaller and net erosion was nil (Figure 4). For the rest of the model, river discharge decreased which slowed the addition of tracer to the seabed, and surface activities of both tracers fell via radioisotopic decay and biodiffusive dilution. Wave-driven erosion that removed high-activity sediments also decreased bed inventory and surface activity late in the model.
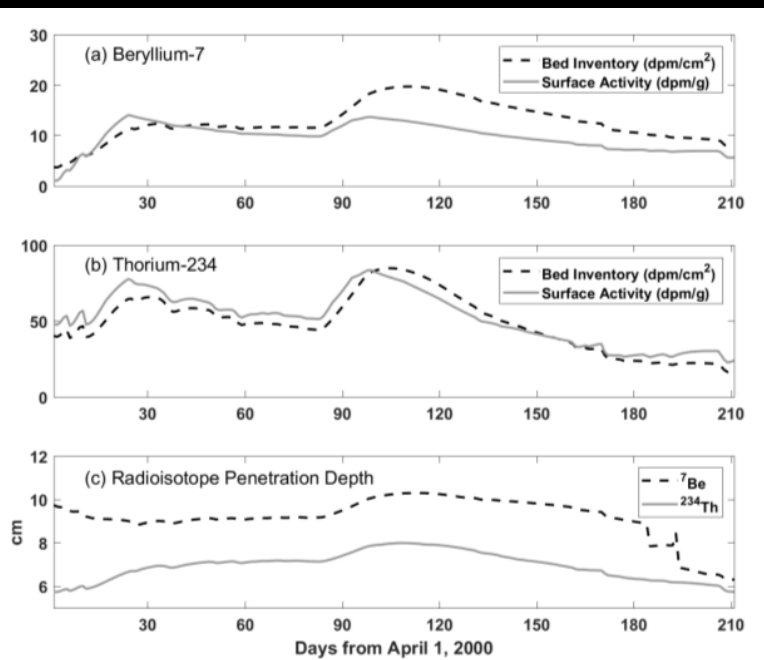

Figure 4: Modeled timeseries of bed inventory and surface activity of (a) ${ }^{7} \mathrm{Be}$ and (b) ${ }^{234} \mathrm{Th}$; (c) penetration depths for ${ }^{7} \mathrm{Be}$ and ${ }^{234} \mathrm{Th}$.
Penetration depths of ${ }^{7} \mathrm{Be}$ and ${ }^{234} \mathrm{Th}$ were initially about $10 \mathrm{~cm}$ and $6 \mathrm{~cm}$, respectively (Figure 4c). Penetration depths of ${ }^{7} \mathrm{Be}$ and ${ }^{234} \mathrm{Th}$ changed slightly until day 100 , after which a large sediment input increased the penetration depth of ${ }^{7} \mathrm{Be}$ and ${ }^{234} \mathrm{Th}$ to $10.5 \mathrm{~cm}$ and $8 \mathrm{~cm}$, respectively. After day 100, declining river discharge and two erosion events decreased the penetration depths of ${ }^{7} \mathrm{Be}$ to about $6 \mathrm{~cm}$ by the end of the model. Penetration depths only loosely corresponded to the sediment input timeseries because of confounding processes of sediment erosion and biodiffusive mixing.

\section{DISCUSSION}

The modeled radioisotope profiles were interpreted using multiple analytical methods that have been applied to sediment core data to estimate the accumulation rate and deposit thickness. These estimated rates were then compared to the modeled accumulation rates and deposit thicknesses.

\section{Accumulation Rate Estimates}

For situations where bioturbation and physical mixing appear to be less influential than deposition, short-lived radioisotopic records from sediment cores are often analyzed to estimate seasonal sediment accumulation rates (Sommerfield, Nittrouer, and Alexander, 1999). Two of these methods were used, that differ in whether they account for biodiffusion, to estimate accumulation rate from the final modeled radioisotopic profiles. These were then compared to the actual accumulation rate: the modeled net deposition divided by the duration of the model run $\left(A_{3}\right)$. The first analytical method applied a steady-state solution that assumed accumulation exceeds the effect of bioturbation (Nittrouer et al., 1984):

$$
A_{1}=\lambda z / \ln \left(C_{0} / C_{z}\right)
$$

where $A_{1}$ represents accumulation rate in $\mathrm{cm} \mathrm{month}^{-1} ; \lambda$ is the decay constant of the radionuclide; $z$ is depth in the seabed; $C_{o}$ is radioactivity at the surface; and $C_{z}$ is radioactivity at depth. The second method accounted for biodiffusion, fitting an advectiondiffusion equation to the final profile (Nittrouer et al., 1984):

$$
A_{2}=\frac{\lambda z}{\ln \left(C_{0} / C_{z}\right)}-\frac{D_{b}}{z}\left(\ln \left(C_{0} / C_{z}\right)\right)
$$

where $D_{b}$ represented the biodiffusion rate in $\mathrm{cm}^{2} \mathrm{yr}^{-1}$.

Compared to the actual value of $\sim 0.66 \mathrm{~cm} \mathrm{month}^{-1}$, the steadystate analytical estimates of accumulation rate varied from net erosion $\left(-0.33 \mathrm{~cm} \mathrm{month}^{-1}\right)$ to double the actual value (Table 1). Rates based on ${ }^{7} \mathrm{Be}$ were more reliable than those from ${ }^{234} \mathrm{Th}$ These analytically-derived values were especially unreliable when biodiffusion was significant (Table 1). Even the steadystate model that accounted for biodiffusion using the correct value of $D_{b, \max }$ had this problem (Table $1, \mathrm{~A}_{2}$, bottom row). These analytical solutions were imprecise because deposition and erosion during the modeled period produced radioisotopic profiles that did not represent steady state conditions (e.g. Sadler, 1999). During erosive periods, radioisotope-tagged sediment was removed from the surface, and what remained was mixed more deeply into the seabed. Resuspension increased ${ }^{234} \mathrm{Th}$ inventory via water column replenishment, which in most cases produced higher apparent accumulation rates based on ${ }^{234} \mathrm{Th}$. 
Table 1: Accumulation rates (cm month ${ }^{-1}$ ) calculated using steady-state analytical solutions for ${ }^{7}$ Be and ${ }^{234}$ Th profiles (columns 2-4), and model accumulation rate calculated by dividing elevation change over the duration of the model by time (column 5). Models were run using various maximum bioturbation rates $\left(D_{b, \max }\right)$, and rates calculated based on final radioisotope profiles.

\begin{tabular}{cccccc}
\hline \hline \multirow{2}{*}{$\begin{array}{c}\mathrm{D}_{\mathrm{b}, \max } \\
\mathrm{cm}^{2} \mathrm{yr}^{-1}\end{array}$} & \multicolumn{2}{c}{$\mathrm{A}_{1}$} & \multicolumn{2}{c}{$\mathrm{A}_{2}$} & \\
\cline { 2 - 5 }$A_{3}=\frac{\text { deposition }}{\text { time }}$ & ${ }^{7} \mathrm{Be}$ & ${ }^{234} \mathrm{Th}$ & ${ }^{7} \mathrm{Be}$ & ${ }^{234} \mathrm{Th}$ & \\
\hline 0 & 0.65 & 0.87 & 0.65 & 0.87 & 0.67 \\
0.95 & 0.70 & 0.89 & 0.66 & 0.81 & 0.67 \\
25 & 1.15 & 1.20 & 0.44 & -0.33 & 0.66 \\
\hline
\end{tabular}

\section{Deposit Thickness Estimates}

Alternatively, episodic seabed elevation changes can be analyzed using non-steady state solutions. Palinkas et al.'s (2005) approach assesses deposit thickness from modeled non-steadystate radioisotope profiles that account for episodic deposition. In this study, the approach was modified to assess relative rates of diffusive bioturbation and net deposition and applied the appropriate advection-diffusion equation (e.g. Nittrouer et al., 1984) to produce an expected ${ }^{7} \mathrm{Be}$ profile between each model time step (Palinkas et al., 2005). If the expected activity profile did not match the observed, a new layer of sediment was added to the top of the seabed with activity equal to the observed surface layer until the calculated profile matched the observed (Palinkas et al., 2005). To test the method using the modeled profiles, this routine was applied to each daily time interval and each seabed layer independently for incremental deposit-layer thicknesses ranging from one to the total seabed thickness. The two calculated profiles with the least amount of deviation above and below the actual deposit thickness at each time were identified and adjusted to the actual deposit thickness. This reconstructed the depositional history with precision (Figure 5), but assumed perfect knowledge of the biodiffusion coefficient and radioisotopic profiles at daily and sub-cm resolution.

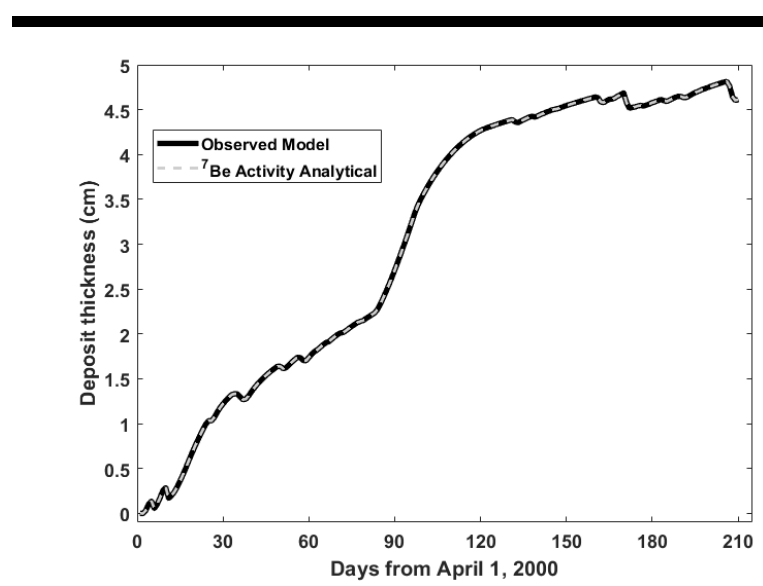

Figure 5: Modeled seabed elevation compared to analytical solution using ${ }^{7} \mathrm{Be}$ activity profiles adapted from Palinkas et al. (2005).
A more likely scenario would be a case where net deposition would be estimated based on sediment cores taken some weeks or months apart. For example, the difference in ${ }^{7} \mathrm{Be}$ inventories in the radioisotopic profiles in Figure 3 could be used to infer depositional history. Applying the methods of Canuel, Martens, and Benninger (1990), deposit thicknesses were estimated for the four time intervals illustrated in Figure 3 and compared to the actual modeled deposition (Table 2). For the first three intervals, which were short, the analytical estimate agreed to within $10 \%$ of the actual deposition. For the final period, however, which covered days 41-210, the analytical approach underestimated the actual deposition by a factor of two (Table 2).

Table 2: Deposition (cm) based on analytical method (Canuel, Martens, and Benninger, 1990) from ${ }^{7}$ Be profiles in Figure 3; and actual model deposition over the same time periods.

\begin{tabular}{ccccc}
\hline \hline & Day 0-24 & Day 24-28 & Day 28-41 & Day 41-210 \\
\hline Analytical & 1.1 & 0.15 & 0.28 & 1.5 \\
Actual & 1.0 & 0.14 & 0.26 & 3.2 \\
\hline
\end{tabular}

This analytical method assumes that all of the new deposition occurs instantaneously, and that the activity of newly deposited sediment equals the activity of surficial sediment at the end of the study period. This method underestimated the actual deposition between days 41-210 because the modeled deposition was somewhat gradual then, but the analytical method assumed that much of the deposition occurred early in the time interval.

\section{CONCLUSIONS}

A combined sediment transport and radioisotope model was applied to a realistic shelf setting to calculate sediment bed profiles representing short half-life radioisotopes ${ }^{7} \mathrm{Be}$ and ${ }^{234} \mathrm{Th}$ that are used to interpret deposition of river derived sediment and sediment resuspension, respectively. This provided an example in a one-dimensional (vertical) model of suspended and seabed sediment of a realistic scenario that evaluated the response of radioisotope profiles to variations in riverine sediment input, storm intensity, and biodiffusion. Success in reproducing the observed profiles measured by Corbett, McKee, and Duncan (2004) for a $50 \mathrm{~m}$ site near the Southwest Pass of the Mississippi River was possible with proper specification of the ${ }^{7} \mathrm{Be}$ and ${ }^{234} \mathrm{Th}$ activities of fluvial and resuspended sediment; and selection of biodiffusion coefficients, deposition, and erosion. Radioisotopic values such as surface activity, inventory, and penetration depth reflect processes operating at timescales ranging from individual floods or storms, to seasonal. Episodic increases and decreases in these values occurred in response to depositional and erosional events, but these were also gradually modified by mixing within the sediment bed, background deposition, and radioisotopic decay.

The model's accumulation rates and deposit thicknesses were compared to values obtained via analytical methods commonly applied to sediment cores. Steady-state analytical estimates of accumulation rate based on ${ }^{7} \mathrm{Be}$ were generally more reliable than those based on ${ }^{234} \mathrm{Th}$ which was enriched via resuspension. For the case using an intense bioturbation rate, the steady-state analytical expressions were imprecise, even Eq. 2 which accounted for biodiffusion. A non-steady state estimate of new deposition reliably calculated the modeled deposit thickness 
when it was run at temporal and spatial resolutions that greatly exceeded those typically achieved by field studies. When applied at the temporal scales more typical of field studies, however, the analytical method of Canuel, Martens, and Benninger (1990) underestimated deposit thickness due to uncertainties in the depositional history.

\section{ACKNOWLEDGEMENTS}

The Bureau of Ocean Energy Management (BOEM) provided funding for Birchler, Harris, and Kniskern. Birchler received additional support from VIMS' Office of Academic Studies. This work was partially supported by the U.S. Geological Survey, Coastal and Marine Geology Program. Use of firm and product names is for descriptive purposes only and does not imply endorsement by the U.S. Government. The authors appreciate input from VIMS' faculty who served on Birchler's M.S. committee: C. Friedrichs, S. Kuehl, and L. Schaffner. The authors thank the anonymous reviewers and J. Moriarty (USGS), whose suggestions helped improve this manuscript. This paper is Contribution No. 3724 of the Virginia Institute of Marine Science, College of William \& Mary.

\section{LITERATURE CITED}

Birchler, J.J., 2014. Sediment Deposition and Reworking: A Modeling Study Using Isotopically Tagged Sediment Classes. Williamsburg, Virginia, USA: The Faculty of the School of Marine Science, the College of William and Mary in Virginia, Master's thesis, $164 \mathrm{p}$.

Birchler, J.J.; Harris, C.K.; Kniskern, T.A., and Sherwood, C.R., submitted, January 2018. Radioisotopic tracers within a sediment transport model: Model description and idealized test cases. Submitted to Continental Shelf Research.

Birchler, J.J.; Harris, C.K., and Kniskern, T.A., 2018. Archive for a numerical model of geochronological tracers for sediment deposition and reworking applied to the Mississippi subaqueous delta. Virginia Institute of Marine Science, College of William and Mary, https://doi.org/10.21220/V5D45C.

Canuel, E.A.; Martens, C.S., and Benninger, L.K., 1990. Seasonal variations in ${ }^{7} \mathrm{Be}$ activity in the sediments of Cape Lookout Bight, North Carolina. Geochimica Cosmochimica Acta 54(1), 237-245.

Corbett, D.R.; McKee, B.A., and Duncan, D., 2004. An evaluation of mobile mud dynamics in the Mississippi River deltaic region. Marine Geology, 209(1), 91-112.

Goñi, M.A.; Alleau, Y.; Corbett, D.R.; Walsh, J.P.; Mallinson, D.; Allison, M.A.; Gordon, E.; Petsch, S., and Dellapenna, T.M., 2007. The effects of Hurricanes Katrina and Rita on the seabed of the Louisiana shelf. The Sedimentary Record, 5(1), 4-9.

Haidvogel, D.B.; Arango, H.; Budgell, W.P.; Cornuelle, B.D.; Curchitser, E.; Di Lorenzo, E.; Fennel, K.; Geyer, W.R.; Hermann, A.J.; Lanerolle, L.; Levin, J.; McWilliams, J.C.; Miller, A.J.; Moore, A.M.; Powell, T.M.; Shchepetkin, A.F.; Sherwood, C.R.; Signell, R.P.; Warner, J.C., and Wilkin, J., 2008. Ocean forecasting in terrain-following coordinates: Formulation and skill assessment of the regional ocean modeling system. Journal of Computational Physics, 227(7), 3595-3624.
Kniskern, T.A.; Mitra, S.; Orpin, A.R.; Harris, C.K.; Walsh, J.P., and Corbett, D.R., 2014. Characterization of a floodassociated deposit on the Waipaoa River shelf using radioisotopes and terrigenous organic matter abundance and composition. Continental Shelf Research, 86(1), 66-84.

McKee, B.A.; DeMaster, D.J., and Nittrouer, C.A., 1984. The use of $234 \mathrm{Th} / 238 \mathrm{U}$ disequilibrium to examine the fate of particle-reactive species on the Yangtze continental shelf. Earth and Planetary Science Letters, 68(3), 431-442.

Moriarty, J.M.; Harris, C.K.; Fennel, K.; Friedrichs, M.A.; Xu, K., and Rabouille, C., 2017. The roles of resuspension, diffusion and biogeochemical processes on oxygen dynamics offshore of the Rhône River, France: a numerical modeling study. Biogeosciences, 14(7), 1919-1946.

Nittrouer, C.A.; DeMaster, D.J.; McKee, B.A.; Cutshall, N.H., and Larson, I.L., 1984. The effect of sediment mixing on $\mathrm{Pb}$ 210 accumulation rates for the Washington continental shelf. Marine Geology, 54(3-4), 201-221.

National Data Buoy Center, 2013. National Oceanographic and Atmospheric Administration's National Data Buoy Center. http://ndbc.noaa.gov/ (accessed June 1, 2013).

Palinkas, C.M.; Nittrouer, C.A.; Wheatcroft, R.A., and Langone, L., 2005. The use of 7Be to identify event and seasonal sedimentation near the Po River delta, Adriatic Sea. Marine Geology, 222-223(1), 95-112.

Sadler, P.M., 1999. The influence of hiatuses on sediment accumulation rates. GeoResearch Forum, 5(1), 15-40.

Shchepetkin, A.F. and McWilliams, J.C., 2005. The regional oceanic modeling system (ROMS): A split-explicit, freesurface, topography-following-coordinate oceanic model. Ocean Modelling, 9(4), 347-404.

Sherwood, C.R.; Aretxabaleta, A.L.; Harris, C.K.; Rinehimer, J.P.; Verney, R., and Ferré, B., (in press, 2018). Cohesive and mixed sediment in the Regional Ocean Modeling System (ROMS v3.6) implemented in the Coupled Ocean Atmosphere Wave Sediment-Transport Modeling System (COAWST r1234). Geoscientific Model Development.

Sommerfield, C.K.; Nittrouer, C.A., and Alexander, C.R., 1999. ${ }^{7} \mathrm{Be}$ as a tracer of flood sedimentation on the northern California continental margin. Continental Shelf Research, 19(3), 335-361.

Warner, J.C.; Sherwood, C.R.; Signell, R.P.; Harris, C.K., and Arango, H.G., 2008. Development of a three-dimensional, regional, coupled wave, current, and sediment-transport model. Computers \& Geosciences, 34(10), 1284-1306.

$\mathrm{Xu}$, K.; Corbett, D.R.; Walsh, J.P.; Young, D.; Briggs, K.B.; Cartwright, G.M.; Friedrichs, C.T.; Harris, C.K.; Mickey, R.C., and Mitra, S., 2014. Seabed erodibility variations on the Louisiana continental shelf before and after the 2011 Mississippi River flood. Estuarine, Coastal and Shelf Science, 149(1), 283-293.

Xu, K.; Mickey, R.C.; Chen, Q.J.; Harris, C.K.; Hetland, R.; Hu, K., and Wang, J., 2016. Shelf sediment transport during Hurricanes Katrina and Rita. Computers \& Geosciences, 90(B), 24-39. 